\title{
Supra Renal Biological Lateralization in Albino Rats
}

\author{
Saad K. Taha*, Salah-Eldin A. Elsayed**, Mariam Y. Ibrahim** \\ Neven M. Aziz** \\ Physiology Depts., Faculties of Medicine, Al-Azhar* and \\ El-Minia** Universities
}

\begin{abstract}
In order to shade light on adrenal biological lateralization and its relation to age, sex, stressful condition and circadian rhythm, the present work was done on 12 groups of rats of both sexes (6 rats in each). These groups were classified according to age (young and adults), sex, condition (non-stress and cold restraint stress) and time of the day (9 am and 9 pm). All animals were anaethetized, dissected to get suprarenal gland on-both sides- out of the abdomen. The glands were weighted, their catecholamines and serotonin were determined by using the spectrofluorophotometer. The results revealed a significant left lateralization of the gland weight and with right lateralization of its hormones in adult rats. Stress did not affect this lateralization. Also, the results showed a significant suprarenal medullary hormones lateralization in female rats compared with the male ones, with circadian lateralization of adult female rats. Data of the present study will open the door for further study, research and investigation about the role of supra-renal biological lateralization on stress developing disease, the role of supra-renal biological lateralization on age \& sex related response to stress and also, circadian relation to stress response.
\end{abstract}

\section{INTRODUCTION}

Vertebrate body is bilaterally symmetrical at the exterior. However, our stomach and heart are oriented towards the left and liver to the right. Asymmetry of the interior is a prominent feature of the vertebrate body plan. Mechanisms by which the Left-Right asymmetry is established, are based on asymmetric gene expression in the embryo ${ }^{(1)}$.

The left adrenal gland was often heavier than the right and with a greater longitudinal length than the right. Adrenal glands were often heavier in male, younger age group (less than 60-yrs-old) and patients with history of hypertension or lung cancers $^{(2)}$.

In human adrenal carcinomas causing Cushing's syndrome occur more frequently on the right side, whereas adrenal tumors inducing primary aldosteronism are more frequent on the left side ${ }^{(3)}$.

The aim of the present work is to shade light on adrenal biological lateralization and its relation to age, sex, stressful condition and circadian rhythm. 


\section{MATERIAL \& METHODS}

Animals:

The present study was conducted on 24 equal young male and female albino rats selected for age (2-3 months), weight (100- 150 grams) and 48 equal adult male and female albino rats selected for age (68 months) and weight (200-250 grams), (4). Rats were housed at room temperature with 12:12 hours light/dark cycles. The rats were fed a standard diet of commercial rat chow and tape water and are conditioned to the room environment for two weeks prior to inclusion in the study (5). Rats were randomly classified into the following groups (6 rats in each group):

I. Non-stressed Male Groups (Control Male Groups):

1.Control young male group at 9 am.

2. Control adult male group at 9 am.

3. Control adult male group at $9 \mathrm{pm}$.

II. Cold Restraint-Stressed (CRS) Male Groups:

1. CRS young male group at 9 am.

2. CRS adult male group at 9 am.

3. Control adult male group at 9 p.m.

III. Non-stressed Female Groups (Control Female Groups):

1. Control young female group at 9 am.

2. Control adult female group at 9 am.

3. Control adult female group at 9 p.m.

IV. Cold Restraint-Stressed (CRS) Female Groups:

1. CRS young female group at 9 am
2. CRS adult female group at 9 am.

3. Control adult female group at $9 \mathrm{pm}$.

Non-stressed rats were left freely wandering in their cages at room temperature.

CRS was done by fixing the four limbs of the rat to a wooden board and placed in a refrigerator at $4^{\circ} \mathrm{C}$ for 3 hours. The door of the refrigerator was opened every 0.5 hour for inspection and follow up ${ }^{(6)}$.

Methods:

The experiments were performed at two times of the day, at 9 a.m. and 9 p.m. to study the effect of the circadian rhythm of the chemical transmitters.

The rats were anesthetized by light ether anesthesia. They were dissected, their supra-renal glands were removed on the right and left sides to determine catecholamines and serotonin.

*Determination of Catecholamines and Serotonin:

According to (Cairlone, 1978) ${ }^{(7)}$ procedure, a weighted whole right and left supra-renal gland were put in a test tube containing $5 \mathrm{ml}$ acidified butanol, the mixture was homogenized and placed in vortex mixer for 30 seconds, then centrifuged for 5 minutes., 1.6 of $0.2 \mathrm{~N}$ acetic acid and $5 \mathrm{ml} \mathrm{n}$-heptane was added to 2.5 of the supernatant fluid. The content was mixed for 30 seconds then, centrifuged for 5 minutes. For 5 HT assay, $1.2 \mathrm{ml}$ of $4 \mathrm{mg} \% \quad \mathrm{O}$ phthaladehyde was added to $0.2 \mathrm{ml}$ of the aqueous phase and mixed well then placed in boiling water path for 10 minutes then cooled under tape water. For catecholamines assay, 0.2 $\mathrm{ml}$ of 0.1 EDETA was added to the 
aqueous phase and mixed well. Then 0.2 of $0.1 \mathrm{~N}$ iodine was added for 2 minutes only. The oxidation was stopped by addition of $0.2 \mathrm{ml}$ of alkaline sulphite for 2 minute exactly (the $\mathrm{pH}$ was adjusted at about 5.4 by addition of $5 \mathrm{~N}$ acetic acid. All samples were subjected for determination of catecholamines and serotonin using spectroflourophotometer (RF-5000, Schmidzu), Japan (Cairlone, 1978) ${ }^{(7)}$. Statistical analysis:

All values are expressed as mean \pm SE. Independent student's " $t$ " test was applied to analyze the significance of differences between mean values and a critical $p$ value was considered to be significant at $<0.05$.

\section{RESULTS}

- The obtained data showed right lateralization in adult rats with insignificant effect in young rats.

- There was a significant lower hormonal concentration in adult rats compared with young rats.

- There was a difference in the circadian rhythm of the epinephrine, dopamine and serotonin as there was a higher epinephrine concentration in right gland and lower dopamine and serotonin concentration in the left gland in adult female rats at $9 \mathrm{pm}$, (Tables 1 , 3 and 4).

- There was insignificant differences in the circadian rhythm of all hormones in adult male rats at 9 pm, except for serotonin (decreased in both glands), (Tables 1-4).

- There was insignificant differences in the circadian rhythm of the hormones in CRS adult male rats at 9 p.m. except for epinephrine, CRS significantly increased concentration in both glands, (Tables 1-4).

- There was a significant difference in the circadian rhythm of the hormones in CRS adult female rats as the concentration increased in right gland except for serotonine, the concentration increased in both glands, (Tables 1-4).

- There was a higher left epinephrine concentration in adult female rats compared with adult male rats with insignificant differences between young rats, (Table 1).

- There was a significant higher left nor-epinephrine concentration in young female rats compared with young male rats with insignificant differences between adult rats, (Table 2).

- There was a significant lower right dopamine concentration in young female rats compared with young male rats with insignificant differences between adult rats, (Table 3).

- There was a significant increased right and left serotonin concentrations in young and adult female rats compared with young and adult male rats, (Table 4).

- There was a significant left lateralization in weight in adult rats and a significant higher weight in both glands in adult rats compared with young rats. CRS insignificantly affect weight of the supra-renal gland. There are insignificant differences in the circadian rhythm in the weight but still left lateralization, (Table 5). 
Table (1): Concentration of Epinephrine In Supra-renal Gland In Male and Female Albino Rats:

\begin{tabular}{|c|c|c|c|c|}
\hline \multirow{3}{*}{\begin{tabular}{|l|}
\multicolumn{1}{|c|}{ Parameters } \\
Control young \\
Mean \pm SE \\
\end{tabular}} & \multirow{2}{*}{\multicolumn{2}{|c|}{$\begin{array}{l}\text { Supra-renal Gland } \\
\text { Male }(\mu g / g) \\
R T\end{array}$}} & \multicolumn{2}{|c|}{$\begin{array}{l}\text { Supra-renal Gland } \\
\text { Female }(\mu g / g)\end{array}$} \\
\hline & & & $R T$ & $L T$ \\
\hline & $572 \pm 72.4$ & $438.5 \pm 80.4$ & $456.3 \pm 78.5$ & $443.3 \pm 78.1$ \\
\hline $\begin{array}{l}\text { CRS young } \\
\text { Mean } \pm \text { SE }\end{array}$ & $625.3 \pm 56.4$ & $489.7 \pm 65.4$ & $557.3 \pm 68.5$ & $490.2 \pm 87.1$ \\
\hline $\begin{array}{l}\text { Control adult } \\
\text { Mean } \pm \text { SE }\end{array}$ & $159.3 \pm 15.3^{\wedge}$ & $101 \pm 20.2^{\bullet} \wedge$ & $178.9 \pm 13^{\wedge}$ & $146.3 \pm 12.2^{\wedge}$ \\
\hline $\begin{array}{l}\text { CRS adult } \\
\text { Mean } \pm \text { SE }\end{array}$ & $145.1 \pm 5.4^{\wedge}$ & $103.1 \pm 9.3^{\bullet} \wedge$ & $251.9 \pm 30^{\bullet} \wedge$ & $171.5 \pm 9^{\bullet} \wedge$ \\
\hline $\begin{array}{l}\text { Control adult at } 9 \text { p.m. } \\
\text { Mean } \pm \text { SE }\end{array}$ & $174.1 \pm 22.3$ & $122.5 \pm 11.3^{\bullet}$ & $293 \pm 25.8^{*}$ & $196 \pm 27.3^{\bullet}$ \\
\hline $\begin{array}{l}\text { CRS adult at } 9 \text { p.m. } \\
\text { Mean } \pm \text { SE }\end{array}$ & $179.1 \pm 9.8$ & $131.2 \pm 12.9^{* \bullet}$ & $206.9 \pm 23.3^{\circ}$ & $125.8 \pm 10.7^{* \bullet \circ}$ \\
\hline
\end{tabular}

Key to the table

Data represents mean \pm S.E. of observations from six animals.

$\%$ Ch.: percentage change. RT: right side in each site.

LT: left side in each site.

-: Significant difference of left side from right side in each site, $P \leq 0.05$.

$\circ$ : Significant difference of female rats from corresponding male group, $P<0.05$.

$\wedge$ : Significant difference of adult from corresponding young group, $P \leq 0.05$.

*: Significant difference of adult at 9 pm from corresponding young group, $P \leq 0.05$. 
Table (2): Concentration of Norepinephrine In Supra-renal Gland In Male and Female Albino Rats:

\begin{tabular}{|c|c|c|c|c|}
\hline \multirow{2}{*}{ Proups } & \multirow{2}{*}{\multicolumn{2}{|c|}{$\begin{array}{l}\text { Supra-renal Gland } \\
\text { Male }(\mu \mathrm{g} / \mathrm{g}) \\
\mathrm{RT} \quad \mathrm{LT}\end{array}$}} & \multicolumn{2}{|c|}{$\begin{array}{l}\text { Supra-renal Gland } \\
\text { Female }(\mu \mathrm{g} / \mathrm{g})\end{array}$} \\
\hline & & & $R T$ & $L T$ \\
\hline $\begin{array}{l}\text { Control young } \\
\text { Mean } \pm \mathrm{SE} \\
\% \text { Ch. from RT side }\end{array}$ & $640.8 \pm 81.1$ & $\begin{array}{l}491.3 \pm 90.1 \\
-23.3\end{array}$ & $704.9 \pm 64.1$ & $\begin{array}{l}640.8 \pm 81.1 \\
-9.1\end{array}$ \\
\hline $\begin{array}{l}\text { CRS young } \\
\text { Mean } \pm \text { SE } \\
\% \text { Ch. from RT side } \\
\% \text { Ch. From control young }\end{array}$ & $\begin{array}{l}704.9 \pm 64.1 \\
+9\end{array}$ & $\begin{array}{l}640.8 \pm 81.1 \\
-9.1 \\
+30.4\end{array}$ & $\begin{array}{l}640.8 \pm 81.1 \\
-9.1\end{array}$ & $\begin{array}{l}576.7 \pm 86 \\
-10 \\
-10\end{array}$ \\
\hline $\begin{array}{l}\text { Control adult } \\
\text { Mean } \pm \text { SE } \\
\% \text { Ch. from RT side } \\
\% \text { Ch. From control young }\end{array}$ & $\begin{array}{l}277.7 \pm 21.4 \\
-56.7^{\wedge} \\
\end{array}$ & $\begin{array}{l}224.3 \pm 14.3 \\
-19.2^{\bullet} \\
-54.3^{\wedge} \\
\end{array}$ & $\begin{aligned} & 266.98 \pm 25.7 \\
&- 62.1^{\wedge} \\
&\end{aligned}$ & $\begin{array}{l}196.5^{ \pm} 13.5 \\
-26.4^{\bullet} \\
-69.3^{\wedge} \\
\end{array}$ \\
\hline $\begin{array}{l}\text { CRS adult } \\
\text { Mean } \pm \text { SE } \\
\% \text { Ch. from RT side } \\
\% \text { Ch. from control adult } \\
\% \text { Ch. from CRS young male }\end{array}$ & $\begin{array}{l}288.4 \pm 32.1 \\
+3.9 \\
-59^{\wedge}\end{array}$ & $\begin{array}{l}225.3 \pm 14.3 \\
-22^{\bullet} \\
+0.4 \\
-65^{\wedge}\end{array}$ & $\begin{array}{l}288.4 \pm 32.1 \\
+8 \\
-55^{\wedge}\end{array}$ & $\begin{array}{l}217.9 \pm 18.1 \\
-24.4 \\
+11 \\
-62.2^{\wedge}\end{array}$ \\
\hline $\begin{array}{l}\text { Control adult at } 9 \text { p.m. } \\
\text { Mean } \pm \text { SE } \\
\% \text { Ch. from RT side } \\
\% \text { Ch. From control adult }\end{array}$ & $\begin{array}{l}256.3 \pm 28.7 \\
-7.7\end{array}$ & $\begin{array}{l}202.9 \pm 10.7 \\
-20.8 \\
-9.5\end{array}$ & $\begin{array}{l}288.4 \pm 32 \\
+8\end{array}$ & $\begin{array}{l}228.5 \pm 34 \\
-21 \\
+16.3\end{array}$ \\
\hline $\begin{array}{l}\text { CRS adult at } 9 \text { p.m. } \\
\text { Mean } \pm \text { SE } \\
\% \text { Ch. from RT side } \\
\text { \% Ch. from control adult at } 9 \text { p.m. } \\
\text { \% Ch. from CRS adult }\end{array}$ & $\begin{array}{l}320.4 \pm 28.7 \\
+25 \\
+11.1\end{array}$ & $\begin{array}{l}256.3 \pm 29.7 \\
-20 \\
+26.3 \\
+13.8\end{array}$ & $\begin{array}{l}256.3 \pm 28.7 \\
-11.1 \\
-11.1\end{array}$ & $\begin{array}{l}179.4 \pm 8.1 \\
-30 \bullet \\
-21.5 \\
-18\end{array}$ \\
\hline
\end{tabular}

\section{Key to the table}

Data represents mean \pm S.E. of observations from six animals.

$\%$ Ch.: percentage change.

$R T$ : right side in each site.

LT: left side in each site.

-: Significant difference of left side from right side in each site, $P \leq 0.05$.

$\circ$ : Significant difference of female rats from corresponding male group, $P<0.05$.

$\wedge$ : Significant difference of adult from corresponding young group, $P \leq 0.05$. 
Table (3): Concentration of Dopamine In Supra-renal Gland In Male and Female Albino Rats:

\begin{tabular}{|c|c|c|c|c|}
\hline \multirow{2}{*}{ Parameters } & \multicolumn{2}{|c|}{$\begin{array}{c}\text { Supra-renal Gland } \\
\text { Male }(\mu \mathrm{g} / \mathrm{g})\end{array}$} & \multicolumn{2}{|c|}{$\begin{array}{l}\text { Supra-renal Gland } \\
\text { Female }(\mu \mathrm{g} / \mathrm{g})\end{array}$} \\
\hline & $R T$ & $L T$ & $R T$ & $L T$ \\
\hline $\begin{array}{l}\text { Control young } \\
\text { Mean } \pm \text { SE } \\
\% \text { Ch. From RT side }\end{array}$ & $401.8 \pm 49.8$ & $\begin{array}{l}249.4 \pm 80.4 \\
-37.9\end{array}$ & $224 \pm 24.8$ & $\begin{array}{l}209 \pm 25.5 \\
-6.7\end{array}$ \\
\hline $\begin{array}{l}\text { CRS young } \\
\text { Mean } \pm \text { SE } \\
\% \text { Ch. from RT side } \\
\% \text { Ch. from control young }\end{array}$ & $\begin{array}{l}253.4 \pm 30.1 \\
-37^{\circ}\end{array}$ & $\begin{array}{l}228.3 \pm 26.4 \\
-9.9 \\
-8.5\end{array}$ & $\begin{array}{l}216 \pm 18.2 \\
-3.6\end{array}$ & $\begin{array}{l}206 \pm 43.7 \\
-4.6 \\
-1.4\end{array}$ \\
\hline $\begin{array}{l}\text { Control adult } \\
\text { Mean } \pm \text { SE } \\
\% \text { Ch. from RT side } \\
\% \text { Ch. from control young }\end{array}$ & $\begin{array}{l}53.4 \pm 1.4 \\
-86.7^{\wedge} \\
\end{array}$ & $\begin{array}{l}42.2 \pm 3 \\
-21 \bullet \\
-83.1^{\wedge} \\
\end{array}$ & $\begin{array}{l}63.97 \pm 4.5 \\
-71.4^{\wedge} \\
\end{array}$ & $\begin{array}{l}45.9 \pm 4.2 \\
-28.2^{\bullet} \\
-78^{\wedge}\end{array}$ \\
\hline $\begin{array}{l}\text { CRS adult male } \\
\text { Mean } \pm \text { SE } \\
\% \text { Ch. from RT side } \\
\% \text { Ch. from control adult } \\
\% \text { Ch. from CRS young } \\
\end{array}$ & $\begin{array}{l}67.7 \pm 9.3 \\
+26.8 \\
-73.3^{\wedge}\end{array}$ & $\begin{array}{l}56.4 \pm 8 \\
-17 \\
+33.6 \\
-75.3^{\wedge} \\
\end{array}$ & $\begin{array}{l}63.2 \pm 3 \\
-1.2 \\
-70.7^{\wedge}\end{array}$ & $\begin{array}{l}54.6 \pm 9.96 \\
-13.6 \\
+19 \\
-73.5^{\wedge}\end{array}$ \\
\hline $\begin{array}{l}\text { Control adult at } 9 \text { p.m. } \\
\text { Mean } \pm \text { SE } \\
\% \text { Ch. from RT side } \\
\% \text { Ch. from control adult }\end{array}$ & $\begin{array}{l}65.7 \pm 10 \\
+23\end{array}$ & $\begin{array}{l}52.2 \pm 3.4 \\
-20.5 \\
+23.7\end{array}$ & $\begin{array}{l}80.7 \pm 11.3 \\
+26.2 \\
\end{array}$ & $\begin{array}{l}68.8 \pm 7.6 \\
-15 \\
+50 *\end{array}$ \\
\hline $\begin{array}{l}\text { CRS adult at } 9 \text { p.m. } \\
\text { Mean } \pm \text { SE } \\
\% \text { Ch. from RT side } \\
\text { \% Ch. from control adult at } 9 \text { p.m. } \\
\text { \% Ch. from CRS adult }\end{array}$ & $\begin{array}{l}67.3 \pm 7.1 \\
+2.4 \\
-0.6\end{array}$ & $\begin{array}{l}47.3 \pm 6.4 \\
-29.7 \\
-9.4 \\
-16.1\end{array}$ & $\begin{array}{l}59.2 \pm 6.8 \\
-26.6 \\
-6.3\end{array}$ & $\begin{array}{l}37.5 \pm 1.1 \\
-36.7^{\bullet} \\
-45.5^{\circ} \\
-31.3^{\circ}\end{array}$ \\
\hline
\end{tabular}

\section{Key to the table}

Data represents mean \pm S.E. of observations from six animals.

$\%$ Ch.: percentage change.

$R T$ : right side in each site.

LT: left side in each site.

-: Significant difference of left side from right side in each site, $P \leq 0.05$.

$\circ$ : Significant difference of female rats from corresponding male group, $P<0.05$.

$\wedge$ : Significant difference of adult from corresponding young group, $P \leq 0.05$.

*: Significant difference of adult at 9 pm from corresponding young group, $P \leq 0.05$. 
Table (4): Concentration of Serotonin in Supra-renal Gland In Male and Female Albino Rats:

\begin{tabular}{|c|c|c|c|c|}
\hline Control voung & \multicolumn{2}{|c|}{$\begin{array}{c}\text { Supra-renal Gland } \\
\text { Male }(\mu g / g)\end{array}$} & \multicolumn{2}{|c|}{$\begin{array}{l}\text { Supra-renal Gland } \\
\text { Female }(\mu g / g)\end{array}$} \\
\hline $\begin{array}{l}\text { Control young } \\
\text { Mean } \pm \text { SE } \\
\% \text { Ch. from RT side }\end{array}$ & $765.6 \pm 100.3$ & $\begin{array}{l}730.4 \pm 59.4 \\
-4.6\end{array}$ & $1260 \pm 20$ & $\begin{array}{l}1180 \pm 100 \\
-6.3\end{array}$ \\
\hline $\begin{array}{l}\text { CRS young } \\
\text { Mean } \pm \text { SE } \\
\% \text { Ch. from RT side } \\
\% \text { Ch. from control young }\end{array}$ & $\begin{array}{l}660.7 \pm 64.4 \\
-13.7\end{array}$ & $\begin{array}{l}697.7 \pm 64.6 \\
+5.6 \\
-4.5\end{array}$ & $\begin{aligned} & 1604.8 \pm 56 \\
+ & 27.4^{\circ}\end{aligned}$ & $\begin{array}{l}1584 \pm 177.4 \\
-1.2 \\
+34.2\end{array}$ \\
\hline $\begin{array}{l}\text { Control adult } \\
\text { Mean } \pm \mathrm{SE} \\
\% \mathrm{Ch} \text {. from } \mathrm{RT} \text { side } \\
\% \mathrm{Ch} \text {. from control young }\end{array}$ & $\begin{array}{l}636.7 \pm 47.6 \\
-16.8\end{array}$ & $\begin{array}{l}467.3 \pm 47.9 \\
-26.6^{\bullet} \\
-36^{\wedge}\end{array}$ & $\begin{array}{l}1043.1 \pm 123 \\
-17.2\end{array}$ & $\begin{array}{l}733.7 \pm 57.7 \\
-30^{\bullet} \\
-37.8^{\wedge}\end{array}$ \\
\hline $\begin{array}{l}\text { CRS adult } \\
\qquad \text { Mean } \pm \mathrm{SE} \\
\% \mathrm{Ch} . \text { from } \mathrm{RT} \text { side } \\
\% \mathrm{Ch} \text {. from control adult } \\
\% \mathrm{Ch} \text {. from CRS young }\end{array}$ & $\begin{array}{l}604.7 \pm 30.5 \\
-5 \\
-8.5\end{array}$ & $\begin{array}{l}413.6 \pm 25.5 \\
-31.6^{\bullet} \\
-11.5 \\
-40.7^{\wedge}\end{array}$ & $\begin{array}{l}825 \pm 63.9 \\
-20.9 \\
-48.6^{\wedge} \\
\end{array}$ & $\begin{array}{l}589.3 \pm 43.6 \\
-28.6^{\bullet} \\
-19.7^{\wedge} \\
-62.8^{\wedge}\end{array}$ \\
\hline $\begin{array}{l}\text { Control adult at } 9 \text { p.m. } \\
\text { Mean } \pm \text { SE } \\
\% \mathrm{Ch} \text {. from RT side } \\
\% \mathrm{Ch} \text {. from control adult }\end{array}$ & $\begin{array}{l}401.1 \pm 58.9 \\
-37 *\end{array}$ & $\begin{array}{l}305.6 \pm 14.7 \\
-23.8 \\
-34.6 * \\
\end{array}$ & $\begin{array}{l}745.4 \pm 48.2 \\
-28.5 * \\
\end{array}$ & $\begin{array}{l}679.6 \pm 30.5 \\
-8.8 \\
-7.4 \\
\end{array}$ \\
\hline $\begin{array}{l}\text { CRS adult at } 9 \text { p.m. } \\
\text { Mean } \pm \text { SE } \\
\% \text { Ch. from RT side } \\
\% \text { Ch. from control adult at } 9 \text { p.m. } \\
\% \text { Ch. From CRS adult }\end{array}$ & $\begin{array}{l}557.8 \pm 69.3 \\
+39.1 \\
-7.7\end{array}$ & $\begin{array}{l}427.8 \pm 50.5 \\
-23.3 \\
+40^{\circ} \\
+3.4\end{array}$ & $\begin{array}{l}1164.5 \pm 114 \\
+56.2^{\circ} \\
+41.2^{*}\end{array}$ & $\begin{array}{l}830.7 \pm 38.8 \\
-28.7^{\bullet} \\
+22.2^{\circ} \\
+41 *\end{array}$ \\
\hline
\end{tabular}

Key to the table

Data represents mean \pm S.E. of observations from six animals.

$\%$ Ch.: percentage change.

RT: right side in each site.

LT: left side in each site.

-: Significant difference of left side from right side in each site, $\mathrm{P} \leq 0.05$.

$\circ$ : Significant difference of female rats from corresponding male group, $\mathrm{P}<0.05$.

$\wedge$ : Significant difference of adult from corresponding young group, $\mathrm{P} \leq 0.05$.

* : Significant difference of adult at $9 \mathrm{pm}$ from corresponding young group, $\mathrm{P} \leq 0.05$. 
Table (5) Lateralization in Supra-renal Gland Weight In Male and Female Albino Rats:

\begin{tabular}{|c|c|c|c|c|}
\hline Parameters & $\begin{array}{c}\text { Right } \\
\text { supra-renal } \\
\text { Male gland } \\
\text { (mg) }\end{array}$ & $\begin{array}{c}\text { Left } \\
\text { Supra-renal } \\
\text { Male gland } \\
\text { (mg) }\end{array}$ & $\begin{array}{l}\text { Right } \\
\text { supra-renal } \\
\text { Female } \\
\text { gland } \\
\text { (mg) }\end{array}$ & $\begin{array}{l}\text { Left } \\
\text { Supra-renal } \\
\text { Female } \\
\text { gland } \\
\text { (mg) }\end{array}$ \\
\hline $\begin{array}{l}\text { Control young } \\
\text { Mean } \pm \text { SE } \\
\% \text { Ch. From RT side }\end{array}$ & $13.3 \pm 2.1$ & $\begin{array}{l}18.3 \pm 3.1 \\
+37.6 \\
\end{array}$ & $11.7 \pm 1.7$ & $\begin{array}{l}13.3 \pm 2.1 \\
+13.7 \\
\end{array}$ \\
\hline $\begin{array}{l}\text { CRS young } \\
\text { Mean } \pm \text { SE } \\
\% \text { Ch. from RT side } \\
\% \text { Ch. from control young }\end{array}$ & $\begin{array}{l}11.7 \pm 1.2 \\
-12 \\
\end{array}$ & $\begin{array}{l}13.3 \pm 2.1 \\
+13.7 \\
-27.3 \\
\end{array}$ & $\begin{array}{l}13.3 \pm 2.1 \\
+13.7 \\
\end{array}$ & $\begin{array}{l}15 \pm 2.2 \\
+12.8 \\
+12.8 \\
\end{array}$ \\
\hline $\begin{array}{l}\text { Control adult } \\
\text { Mean } \pm \mathrm{SE} \\
\% \mathrm{Ch} \text {. from } \mathrm{RT} \text { side } \\
\% \mathrm{Ch} \text {. from control young }\end{array}$ & $\begin{array}{l}28.3 \pm 1.7 \\
+555^{\wedge} \\
\end{array}$ & $\begin{array}{l}35 \pm 2.2 \\
+24^{\bullet} \\
+91.3^{\wedge} \\
\end{array}$ & $\begin{array}{l}30 \pm 2.6 \\
+589^{\wedge} \\
\end{array}$ & $\begin{array}{l}40 \pm 2.6 \\
+33.3^{\bullet} \\
+799^{\wedge}\end{array}$ \\
\hline $\begin{array}{l}\text { CRS adult } \\
\text { Mean } \pm \text { SE } \\
\% \text { Ch. from RT side } \\
\% \text { Ch. from control adult } \\
\% \text { Ch. from CRS young }\end{array}$ & $\begin{array}{l}28.4 \pm 3.1 \\
+0.4 \\
+502 \wedge \\
\end{array}$ & $\begin{array}{l}36.7 \pm 2.1 \\
+30^{\bullet} \\
+4.9 \\
+787^{\wedge} \\
\end{array}$ & $\begin{array}{l}28.3 \pm 3.1 \\
-5.7 \\
+400^{\wedge} \\
\end{array}$ & $\begin{array}{l}36.7 \pm 3.3 \\
+30^{\bullet} \\
-8.3 \\
+547^{\wedge} \\
\end{array}$ \\
\hline $\begin{array}{l}\text { Control adult at } 9 \text { p.m. } \\
\text { Mean } \pm \text { SE } \\
\% \text { Ch. from RT side } \\
\% \text { Ch. From control adult }\end{array}$ & $\begin{array}{l}31.7 \pm 3.1 \\
+12 \\
\end{array}$ & $\begin{array}{l}38.3 \pm 1.7 \\
+21^{\bullet} \\
+9.4\end{array}$ & $\begin{array}{l}28.3 \pm 3.1 \\
-5.7\end{array}$ & $\begin{array}{l}36.7 \pm 4.2 \\
+29.7^{\bullet} \\
-8.3\end{array}$ \\
\hline $\begin{array}{l}\text { CRS adult at } 9 \text { p.m. } \\
\text { Mean } \pm \text { SE } \\
\% \text { Ch. from RT side } \\
\% \text { Ch. from control adult at } 9 \text { p.m. } \\
\% \text { Ch. from CRS adult }\end{array}$ & $\begin{array}{l}25 \pm 2.2 \\
-21.1 \\
-12\end{array}$ & $\begin{array}{l}31.7 \pm 3.1 \\
+26.8 \\
-17.2 \\
-13.6\end{array}$ & $\begin{array}{l}31.7 \pm 3.1 \\
+12 \\
+12 \\
\end{array}$ & $\begin{array}{l}43.3 \pm 2.1 \\
+36.6^{\bullet} \\
+18 \\
+18\end{array}$ \\
\hline
\end{tabular}

\section{Key to the table}

Data represents mean \pm S.E. of observations from six animals.

$\%$ Ch.: percentage change.

$R T$ : right side in each site.

LT: left side in each site.

-: Significant difference of left side from right side in each site, $P \leq 0.05$.

$\wedge$ : Significant difference of adult from corresponding young group, $P \leq 0.05$. 


\section{DISCUSSION}

Data of the present study showed a significant left lateralization of the weight of supra-renal glands. Sullivan and Gratton, (1999) ${ }^{(8)}$ reported a leftbiased asymmetry in the supra-renal gland weights and the stress did not differentially affect this gross measure. Also, the supra-renal gland weight was higher in adult compared with young rats due to normal growth and development of the adult. On the other hand, Susane et al (2003) ${ }^{9}$ found that mice had larger left than right adrenals and this asymmetry was abolished in exercising animals, mainly because of enlargement of the right adrenal gland. In contrast to this observation in exercising mice other researchers observed substantially enlarged adrenal medulla in animals and man after exercise training ${ }^{(\mathbf{1 0 , 1 1 \& 1 4 )} \text {. }}$

A related results found by Szigethy et al. (1994) ${ }^{(13)}$ who found a left-right adrenal weight asymmetry in suicides, they attributed this asymmetry to the consistency with the hypothesis of abnormal lateralized input from higher control centers of the HPA axis.

Aging is frequently associated with changes in physiological and cognitive process, among these changes is a distinict dysregulation of the hypothalamic-pituitary-adrenal axis (HPA), the obtained data revealed that there was a higher serum norepinephrine and lower epinephrine in the young rats compared with adult rats and this may be explained by immaturity of the phenylethanolamine-N-methyl transferase enzyme in young rats. This finding is in accordance with Avakian et al (1984) $^{(\mathbf{1 4})}$ who found that arterial plasma epinephrine concentration in older rats is significantly elevated both in basal conditions and in response to acute cold stress suggesting enhanced adrenal medullary activity with advancing age. But, Pascualy et al. (1999) ${ }^{(15)}$ found that norepinephrine and epinephrine levels both basal and after cold pressor test were significantly higher in advanced aging than in young subjects but Ester et al. (2002) ${ }^{(\mathbf{1 6})}$ found that adrenal medullary release of epinephrine was subnormal in the elderly, at rest and during stress in man.

These findings may be explained either by Kawano et al (1995) ${ }^{(17)}$ and Mabry et al (1995) ${ }^{(\mathbf{1 8 )}}$ who stated that sympathetic-adrenal medullary activities increase with age under resting conditions in rats. But, Mc Cart (1986) ${ }^{(19)}$ and Cizza et al $\mathbf{( 1 9 9 5 )}^{(\mathbf{2 0 )}}$ concluded that aging is associated with diminished responsiveness of central and peripheral catecholaminergic system to acute stress.

The obtained data revealed that there were significant higher suprarenal medullary hormones in female rats compared with male rats and this may be due to high level of glucocorticoid hormone, which is the major factor that controls the synthesis and release of catecholamines from supra-renal gland, in females compared with males. These results agree with Born et al. (1995) $)^{(21)}$ who reported that there were greater levels of adreno- 
corticotropic hormone (ACTH) and corticosterone levels in females compared with males.

Leniewska et al
concluded that the responsiveness of the pituitary-adrenal cortex axis of female rats to stress depends on stimulatory or facilitatory effect of estradiol.

Our findings may be explained by Weinstock et al (1998) ${ }^{(23)}$ who found that males have significantly higher plasma DHPG/NE ratio but lower plasma levels of COR and EP than females. $\{\mathrm{NE}$, norepinephrine, COR, corticosterone,

DHPG, dihyroxyphenylglycerol [NE metabolites]\}. And stress increased EP \& NE \& COR and DHPG in both sexes (EP, epinephrine). They showed also that the female sympathoadrenal system is more reactive than that of the male to the stress Renard et al $\mathbf{( 2 0 0 5 )}^{\mathbf{( 2 4 )}}$ found that there are sexinduced effects in emional reactivity, perception of the stressor and in the evaluation of novel situation and Kurina et al (2005) ${ }^{(25)}$ suggested that the genetic determinants of morning cortisol levels may be different for men and women.

The obtained data revealed right lateralization of the supra-renal hormones in adult rats and the stress did not affect this lateralization. These results agree with Gerendai and Halasz (2001) ${ }^{(3)}$ who reported that there was a predominant right-sided neuronal structure in the control of supra-renal gland. Also, there was a positive correlation between suprarenal weight and total cortical thickness in both right and left glands so with lower weight of right gland compared with left, cortical thickness decreased and increase thickness of medulla releasing more catecholamines $^{(\mathbf{1 3})}$.

Our data showed higher suprarenal medullary hormones in female rats compared with male rats and these results agree with Born et al. $\mathbf{( 1 9 9 5 )}^{(\mathbf{2 1})}$ who reported that there were greater levels of adreno-corticotropic hormone $(\mathrm{ACTH})$ and corticosterone levels in females compared with males, but the picture is more complex in humans as men seem to secrete more ACTH than women with comparable total cortisol levels under basal conditions, which suggest an increased sensitivity of female adrenal cortex and as a result secrete more medullary hormones. This results in agreement with Kurina et al (2005) $^{(25)}$ who suggested that the genetic determinants of morning cortisol levels may be different for men and women.

In recent decades intensive research on the behavior of neuropeptides has revealed asymmetries in their distribution in the brain, and there is evidence that the lateralized patterns of distribution are involved in the regulatory control of some neuropeptidase activities. Therefore, if these enzymatic activities are distributed asymmetrically, their endogenous substrates would presumably be affected in an asymmetrical way, as would the functions they are involved in $^{(26)}$.

The obtained data revealed that cold restraint stress significantly increased the serum catecholamines and this result agrees with Desborough (2000) ${ }^{(27)}$ who reported that the stress enhanced release of 
catecholamines from supra-renal medulla under the effect of increased sympathetic activity, Mabry et al $(1995)^{(\mathbf{1 8})}$ who found that aged rats have exaggerated sympathetic-adrenal medullary responses to acute swim stress than young rats. And these aged-related alteration in plasma catecholamine responses to acute stress may influence spatial memory performance of rats, Mabry et al $\mathbf{( 1 9 9 5 )}^{(\mathbf{2 8})}$ found that aged rats have enhanced plasma catecholamine responses to acute restraint stress compared to young adults, Livezey et al (1985) $)^{(29)}$ found that individual rats responded differently to immobilization and females usually showed higher stress values.This catecholamine stress-induced increase explained by Mc Carly et al $(\mathbf{1 9 9 1})^{\mathbf{( 3 0 )}}$ who indicated that rotation stress provides a selective activation of epinephrine-containing adrenal chromaffin cells as reflected in an increase in plasma $\mathrm{E}$ but not NE.

Also, our results agree with Pertsov et al (2003) ${ }^{(31)}$ who reported that the difference in the content of catecholamines in left and right adrenal glands of control and stressed rats may reflect asymmetry of secretory activity in the adrenal gland.

Exposure to various mild stressor has been shown to result in the activation of dopamine containing neuronal systems projecting to the PFC.Our results also showed a reduction in dopamine concentration in young female rats which agree with the finding of Ivanisevic et al (1997) $^{(\mathbf{3 2})}$ found a reduction basal dopamine concentration in adrenal glands and an increase in response to stress at all ages in female rats. While the greatest values of $\mathrm{E}$ and $\mathrm{NE}$ were found in older females. The stress response of NE and dopamine had a tendency to fall reaching basal values in old females.

The data of the present work showed a significant increase in serotonin concentration in female groups compared to the male groups which can be explained by Handa et al (1993) ${ }^{(33)}$ who postulated that increased serotonin neurotransmission can normalize the hyperactivation of the hypothalamic-pituitary-adrenal axis of old male rats. Handa et al (1996) $^{(\mathbf{3 4})}$ reported that serotonin activity could be involved in the agerelated changes in the MFC catecholamine responses to stress in female rats.

In adult rats, the data of the present work show a higher epinephrine concentration in right gland and lower dopamine and serotonin concentration in the left glands in female rats and a low concentration in both glands in male rats at $9 \mathrm{pm}$. CRS increases epinephrine concentration in both glands in male rats at $9 \mathrm{pm}$. However, it induces a significant difference in the circadian rhythm of the hormones in CRS adult female rats as the concentration increased in right gland except for serotonin the concentration increased in both glands. In a similar work, Allen et al (1980) ${ }^{(35)}$ found that a circadian rhythm of plasma corticosterone levels and adrenal content in both male and female with the highest levels at the onset of darkness. In contrast no circadian rhythm of ACTH. They concluded that rhythmic corticosterone secretion is not entirely dependent on $\mathrm{ACTH}$ 
secretion. Also, Kant et al (1986) ${ }^{(\mathbf{3 6})}$ found that stress at 6:00 increased pituitary cyclic AMP 10-fold, while stress applied at 18:00 did not significantly increase pituitary cyclic AMP levels. This pituitary cyclic AMP is involved in the stress-induced release or synthesis of the pituitary ACTH.

Abizaid et al (2004) $)^{(37)}$ concluded that estradiol hormones play an important role in the tuning of the clock in the face of environmental changes in daylight. Minami et al $\mathbf{( 1 9 8 2 )}^{\mathbf{( 3 8 )}}$ found significant increases in urinary norepinephrine \& epinephrine and dopamine. Cold exposure produced a significant increase in NE and E in both light and dark phase.

Rybkin et al (1997) ${ }^{(39)}$ found that there was an elevation of dopamine turnover in the hypothalami of rats restraint at the end of light cycle, but not those restraint in the morning. These results show that restraint stress has a greater effect on metabolism and energy balance when it is applied in the morning.

There is no direct work done similar to this work but our data can be explained by Oster (2006) ${ }^{(\mathbf{4 0 )}}$ who reported that the mammalian circadian pacemaker residing in the suprachiasmatic nuclei (SCN) of the hypothalamus control peripheral clocks throughout the brain and the body via humoral and neuronal transmission. They concluded that there is a tissue specificity of some component of these molecular clockworks and the regulation of their rhythmicity by the SCN. Pickard and Turek (1982) ${ }^{\mathbf{( 4 1 )}}$ reported that there are at least two pacemakers and an interaction between the bilaterally paired suprachiasmatic nuclei in the generation of the circadian rhythm of activity.

In 2003, de la Iglesia et al. ${ }^{(42)}$ provided the first functional evidence of "splitting" phenomenon of the output pathway from the SCN. They concluded that the functional activity of the neuroendocrine hypothalamus mirrors intrinsic side-to-side differences in the SCN gene expression. Buijs et al. (1999) ${ }^{(43)}$ proved a functional neuronal connection between SCN and adrenal gland and they concluded that SCN utilizes this neuronal pathway to spread its time of the day message to the adrenal gland, utilizing the autonomic nervous system. They found that at the beginning of dark period there is a fast decrease of corticosterone accompanied by constant basal levels of blood adrenaline and noradrenaline, they proposed this due to a direct inhibition of the neuronal output to the adrenal cortex by light-mediated activation of SCN neurons.

Moyer and Kennaway, (2000) $^{(\mathbf{4 4})}$ reported that $\mathrm{SCN}$ is the locus of the biological clock in mammals. Daily light cycles entrain the endogenous circadian rhythm through direct and indirect neural pathways from the retina. They proved that serotonin is a mediator of these photic information to the SCN.

Tavakoli et al (2006) ${ }^{(45)}$

observed an obvious asymmetry of the c-fos expression of the lateral habenula (the circadian timing system in rodents.

Linder

(2003) $^{(46)}$

demonstrated that heavy exercise had 
a significant effect on cortisol release immediately post exercise, but not significantly affect the waking circadian rhythm in women.

In conclusion, this study revealed a peripheral biological lateralization in the supra-renal glands. Data of the present work will open the door for further study on: the role of this lateralization on stress responses and in the pathogenesis of stress developing diseases, the role of neurochemical lateralization differences between young adult male and female in age and sex related response to stress, and the relation between central and peripheral endocrine lateralization and the role of dark-light cycle of neurochemical lateralization on hormonal release during day and night (Hormonal circadian rhythm)

\section{REFERENCES}

1. Bakalkin, G.Y.; Tsibezov, V.V; Sjutkin, E.A.; Veselova, S.P.; Novikov, I.D. and Krivosheev, O.G. (1984): Lateralization of LHRH in rat hypothalamus. Brain Res, 296: 361-364.

2. Lam, K.Y.; Chan; A.C and Lo, C.Y. (2001): Morphological analysis of adrenal glands: a prospective analysis. Endocr. Pathol. Spring; 12(1): 33-8.

3. Gerendai, I. and Halász, $B$. (2001): Asymmetry of the Neuroendocrine System. News Physiol Sci, 16: 92-95.

4. Cano, P.; Cardinali, D.P.; Chacon, F.; Castrillion P.O.; Carlos A. and Esquifino, A.I. (2001): Age-dependent changes in 24-hour rhythms of catecholamine content and turnover in hypothalamus, corpus striatum and pituitary gland of rats injected with Freund's adjuvant. BMC Physiology, 1:14.

5. Noriyoshi, S.; Masaru, Y.; Takemi, G. and Yoshimitsu, A. (2000): Stimulation of prostaglandin E2 and interleukin-1ß production from periodontal ligament cells of old rat subjected to mechanical stress. Journal Gerontology; 55:B489 - B495.

6. Bhatnagar, S.; Dallman, M.; Roderick, R.; Basbaum, A. and Taylor, B. (1998): The effect of prior chronic stress on cardiovascular response to acute restraint and formalin injection. Brain Res., 797(2): 313-320.

7. Ciarlone (1978): Determination of catecholamines spectrophotoflurometrically. Am. J. Physiol., 125:731-737.

8. Sullivan, E.M. and Gratton, A. (1999): Lateralized effects of medial prefrontal cortex lesions on neuroendocrine and autonomic stress responses in rats. J Neurosci, 19: 2834-2840.

9. Susanne KD, Gesing A, Ulbricht S, Mueller BM and Reul JMH (2003): Effect of long-term voluntary exercise on the mouth hypothlmic-pituitaryadrenocortical axis. Endocrinology 177(7):30123023.

10. Stallknecht B; Kjaer M.; Ploug T.; Maroun L.; Ohkuwa T.; Vinten J.; Mikiines KJ. And Galbo H (1990): Diminshed epinephrine response to 
hypoglycemia despite enlarged adrenal medulla in trained rats. A J Physiol 259:R998-R1003.

11. Schmidt KN.; Gosselin LE Stanley WC. (1992): Endurance exerices training causes adrenal medullar hypertrophy in young and old Fischer 344 rats. Horm Metab Res. 24:511-515.

12. Kjaer M (1998): Adrenal medulla and exercise training. Eur J Appl Physiol 77:195-199.

13. Szigethy E, Conwell Y, Forbes NT, Cox C and Caine EI (1994): Adrenal weight and morphology in victim of completed suicide. Biol Psychiatry.; 36(6):374-80.

14. Avakian EV, Horvath SM and Colbum RW (1984): Influence of age and cold stress on plasma catecholamine levels in rats. J Aulon Nerv. Syst. 10(2):127-33.

15. Pascualy M, Petrie EC, Brodkin $K$ and Raskind MA (1999): Effect of advanced aging on plasma catecholamine response to the cold pressor test. Neurobiol. Aging 20(6):637-42.

16. Ester M, Lambert G, Kaye D and Seals DR (2002): Influence of aging on the sympathetic nervous system and adrenal medulla at rest and during stress. Biogerontology 3(1-2):45-9.

17. Kawano S, Ohmori S Kamble and Seo $H$ (1995): Catecholamine responses to stress: age related modification in tail suspended rats. Environ Med., 39(2):107-11.

18. Mabry TR, Gold PE and Mc Carty R (1995a): Age-related changes in plasma catecholamine responses to acute swim stress. Neurobiol. Learn Mem 63(3):260-8.

19. Mc Carty R (1986): Age-related alteration in sympathetic-adrenal medullary responses to stress. Gerontology 32(3):172-83.

20. Cizza G, Gold PW and Chrousos GP (1995): Aging is associated in the $344 / \mathrm{N}$ Fischer rat with decreased stress responsivity of central and peripheral catecholaminergic system and impairment of the hypothalamic-pituitary-adrenal axis. Ann NY Acad Sci; 771:491-511.

21. Born, J.; Distschuneit, I.; Scihreiber, M.; Dodt, C. and Fehm, H.L. (1995): Effects of age and gender on the pituitaryadrenocortical responsiveness in humans.Eur. J. Endocrinol, 132:705-11.

22. Lesniewska B.; Miskowiak B.; Nowak M.; Malndowicz LK. (1990): Sex differences in adrenocortical structure and function. XXVII. The effect of ether stress on ACTH and corticosterone in intact, gonadectomized, and testosterone- or estradiolreplaced rats. Res Exp. Med (Berl):190(2):95-103.

23. Weinstock M, Razin $\mathbf{M}$ Schore-Apeebaum D and Mc Cart R (1998): Gender differences in sympathoadrenal activity in rats at rest and in response to footshock stress. Int J Dev Neurosci 16(3-4_:289-95.

24. Renard GM, Suarez MM Levin GM and Rivarola MA (2005): Sex differences in rats: effect of chronic stress on 
sympathetic system and anxiety. Physiol Behav.:85(3):363-9.

25. Kurina ML, Laurena AW, Steven WG and Carole O (2005): Sex difference in the genetic basis of morning serum cortisol levels. J Clin Endocrinol Metab. 90:4747-4752. Stress; 7(2):131-43.

26. Manuel R.; Isabel P.; Francisco V. and Francisco A. (2004): Neuropeptides, Neuropeptidases and Brain Asymmetry. Current Protein and peptide Science, (5)6:497506(10).

27. Desborough, J.P. (2000): The stress response to trauma and surgery. British J. Anaesthesia, 85(1): 109-117.

28. Mabry TR, Gold PE and Mc Carty R (1995b): Age-related changes in plasma catecholamine responses to chronic intermittent stress. Physiol. Behav. 58(1):49-56.

29. Livezey GTm Miller JM and Vogel WH (1985): Plasma norepinephrine and epinephrine and corticosterone stress response to restraint in individual male and female rats and their correlation. Neurosci. Lell.,20:62(1)51-6.

30. Mc Carly R, Eisen G and Barholow Cl (1991): Plasma catecholamine responses to acute motion stress in laboratory rats. Physiol. Behav.;49(3):653-6.

31. Pertsov S.S.; Koplik EV.; Krause W.; Michael N.; Sudakov KV (2003): Catecholamine content in the adrenal glands of August and Wistar rats after acute emotional stress. Proc. Of the Natl. Academy of Science of Belarus, Ser. Medical biological Sci., (2):34.

32. Ivanisevic-Milovanovic OK, Demoy OM, Loncarstevanovic $H$ and Pantic $V$ (1997): Basal and stress induced concentrations of adrenal gland catecholamines and plasma ACTH during aging. Acta Phsiol Hung.; 85(1):65-75.

33. Handa RJ, Cross KM, George $M$, and Lorens SA (1993): Neuroendocrine and neurochemical responses to novelty stress in young and old male F344 rats: effect of age and d-fenfluramine treatment. Pharmacol Biochem Beh.; 46(1):101-9.

34. Handa RJ, George M, Gordon BH and Lorens SA (1996): Responses to novelty stress in female F344 rats: effect of age and d-fenfluramine treatment. Pharmacol Biochem Beh.; 53(3):641-7.

35. Allen-Rowlands CF.; Allen JP.; Green MA. And Wilson M. (1980): Circadian rhythmicity of ACTH and corticosterone in the rat. $\mathrm{J}$ Endocrinol. Invest.;3(4):371-7.

36. Kant GJ; Mouyer EM and Meyerhof JL. (1986): Diurnal variation in neuroendocrine response to stress in rats: plasma ACTH, beta-endorphin, betaLPH, corticosterone, prolactin and pituitary cAMP response. Neuroendocrinology, 43(3):38390.

37. Abizaid A; Meyer G and Horvath TL. (2004): Estradiol 
enhances light-induced expression of transcription factors in the SCN. Brain Res., 4;1010(1-2)35-44.

38. Minami M; Togashi H; Yasuda H. and Saito H. (1982): Changes in circadian rhythm of urinary catecholamine excretion in cold-restraint spontaneously hypertensive rats. Hokkaido Igaku Zasshi;27(5);55-6.

39. Rybkin H., Zhou Y.; Volaufova J. and Harris RB. (1997): Effect of restraint stress on food intake and body weight is determined by time of day. Am J. Physiol. 273(5Pt2):R1612-22.

40. Oster $H$ (2006): The genetic basis of circadian behavior. Genes, Brain \& Behavior. 5:73.

41. Pickard GE., and Turek FW.: Splitting of the circadian rhythm of activity is abolished by unilateral lesion of the suprachiasmatic nuclei. Science 26; 215(4536):1119-21.

42. de la Iglesia Hog, Meyer J., Schwartz W J (2003): lateralization of circadian pacemaker output: Activation of left- and right- sided luteinizing hormone-releasing hormone neurons involves a neural rather than a humoral pathway. Neuroscience 23(19):7412-4.

43. Buij RM, Wortel J, Van HJJ, Romijn HJ and Kalsbeek A (1999): Anatomical and functional demonstration of a multisynaptic supra-chiasmatic nucleus adrenal cortex pathway. Eur J Neurosci., 11(5):1535-44.

44. Moyer RW and Kennaway DJ (2000): Serotonin depletion decreases light induced c-fos in the rat suprachiasmatic nuclei. Neuroreport, 11(5):1021-4

45. Tavakoli NM, Nezhad $\mathbf{M}$ and Schwartz WJ (2006): Hamsters running on time: is the lateral habenula a part of the clock. Chronobiol. Int. 23(1-2):217-24.

46. Linder E. Elizabeth, (2003): The effect of Heavy Resistance Exercise on the Circadian Rhythm of Salivary Cotisol in Women. UW-L J of Undergraduate Res. VI, 1-4. 


\title{
الجانبية البيولوجية للغدة فوق الكلوية في الفئران البيضاء
}

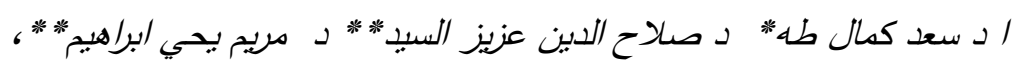

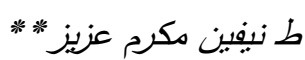

قسمي الفسيولوجي ، كليتي الطب ، جامعة الأزهر * و جامعة المنيا عزين

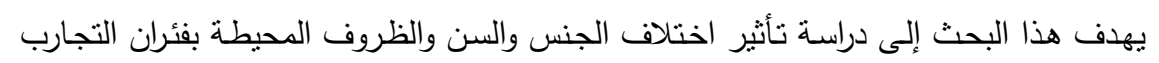
(ظروف عادية و إجهاد بالتثبيت والتعريض للبرد ) صباحا ومساءا على بعض التهن النواقل الكيميائية

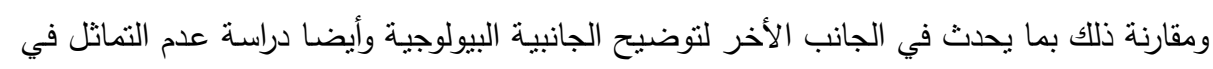

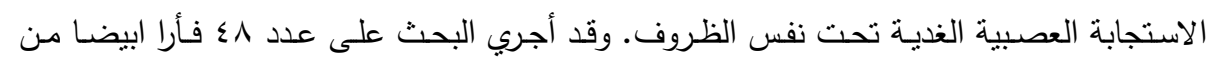

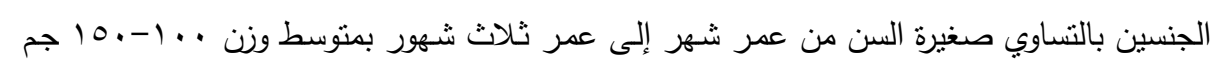

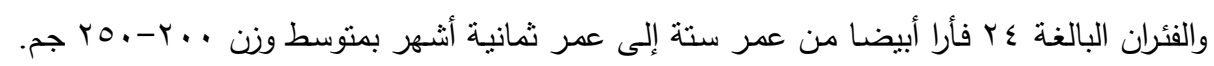

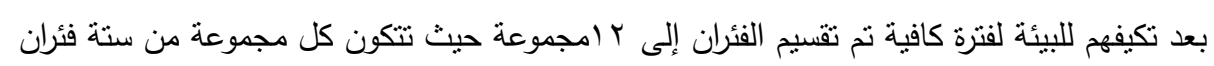

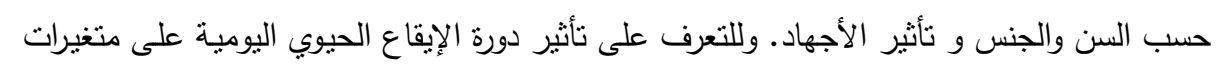

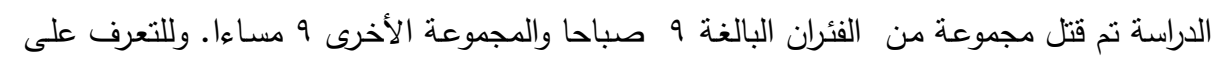

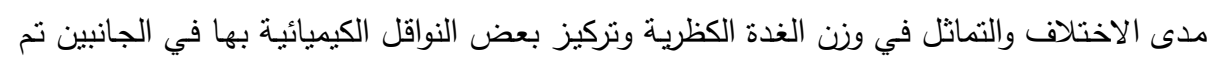

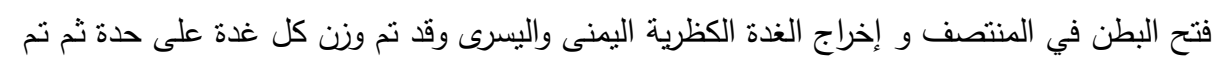

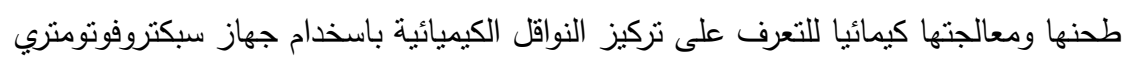
أظهرت الدراسة وجود سيادة يمني في الفئران البالغة ومع الأجهاد تختفي مع الأدينائالينالين.

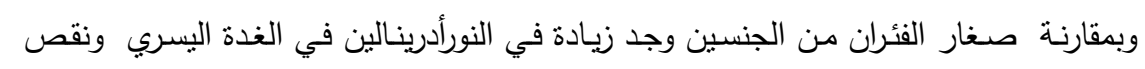

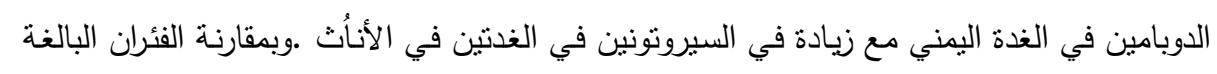

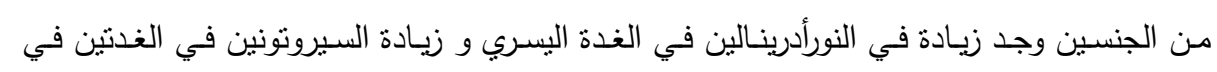

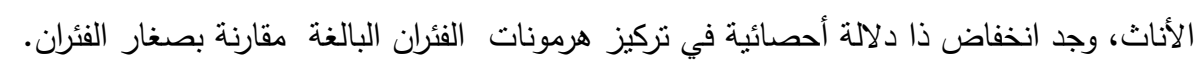

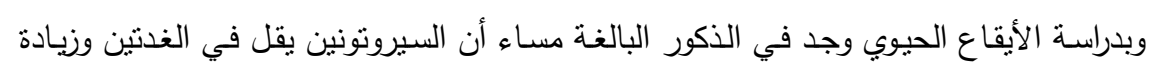

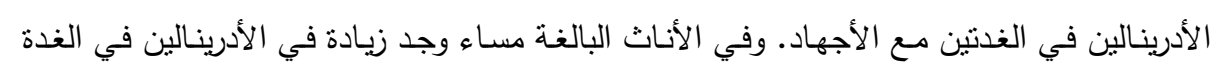

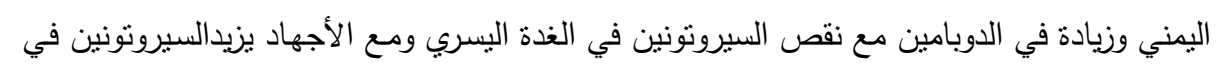
الغدنين. 
و قد وجد سيادة بسرى في وزن الغدة الكظرية في الفئران البالغة.و زيادة في وزن الغدتين في الفئران

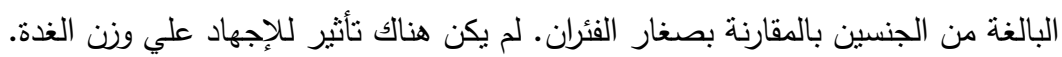

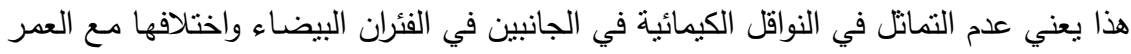

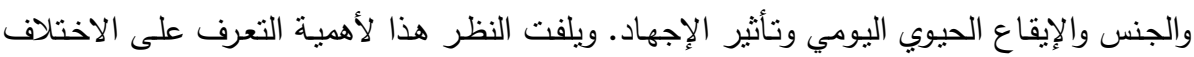

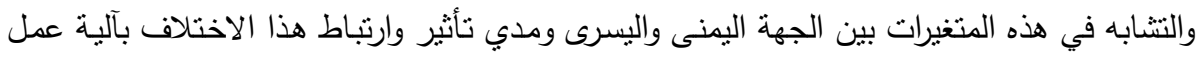

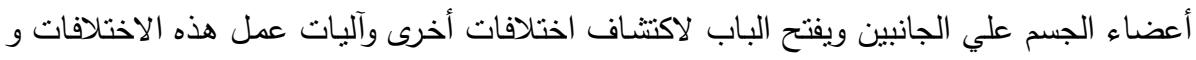
دور ذلك في الأمراض المرتبطة بالتوتر والأجهاد وقد بيساعد أيضا في تفسير اختلاف استجابة الأناث

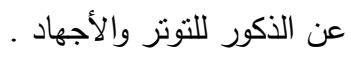

